\title{
Legal Developments on Women's Rights to Inherit Land under Customary Law in Tanzania
}

\author{
By Rose Mtengeti-Migiro
}

\section{Introduction}

The position of women in the political and socio-economic fabric of a society serves as a reliable indicator of that society's potential for development. In 1967 the now retired President Julius Nyerere, speaking of the inequality between men and women, said: "If we want our country to make full and quick progress now, it is essential that our women live in terms of full equality with their fellow citizens who are men." 1 This was the pillar against which the country's policy of Socialism and Self-reliance rested, to build a society of equal and free citizens. The Constitution of the United Republic of Tanzania, 1977, declared in the Preamble that its aims and objectives were to guarantee freedom and justice founded upon the principle that all human beings are equal. Thus it was seen as the duty of the entire community to consolidate and maintain the inherent dignity of human beings in accordance with the Universal Declaration of Human Rights 2 . However, in practice, these policy and constitutional pronunciations were not taken as sufficient to guarantee women's equal rights in all spheres of life.

The glaring inequality in women's rights to inherit land was, until recently, a living example. As women battled and scored one victory after another in asserting their position and rights in society, the "sensitive" land clog reinforced by traditional and cultural attitudes of a predominantly patrilineal society, remained unmoved. The entrenchment of the Bill of Rights for the first time in the country's Constitution in 1985 was received with mixed feelings. Optimists looked at it as a final guarantee of women's rights in every aspect of life while others hardly believed that the judiciary would be bold enough to upset customary law. This paper sets to examine the question of inheritance rights to land, one of the most controversial legal issues conceming women since the country's independence about three decades ago now.

1 Nyerere, JK., Socialism and Rural Development, in: Ujamaa Essays on Socialism, Dar es Salaam, OUP, 1974, p. 109.

2 Para. c (v) of the Constitution of the United Republic, 1977, before the 1984 Fifth Amendment. 


\section{Inheritance Rights in Traditional Society}

In order to appreciate the nature of women's inheritance rights in contemporary Tanzania it is important to understand the rules in the context of the early traditional society in which they have their origin. Before the advent of colonial domination, social organization was based on clans of people who traced their origin to a common ancestor. The clan comprised single families headed by a male. Land, which was the major means of livelihood and also the main form of property, was collectively owned by the clan but it was apportioned to family units under the authority of the head of the family, who was male. Heads of families were enjoined to preserve that land so that it would be available for the family members' use at all times. As it were males who bore the duty of carrying family lineage, land was in fact held in trust for male members of the clan. Thus, upon death, it passed from one male heir to another. In this context females were excluded from "inheriting" family or clan land. There were two reasons for this. First it was considered that a daughter would marry and settle on her husband's clan land, and secondly the exclusion was intended to keep out strangers (husbands) from "interfering" in matters of another clan. But on the other hand, a wife was not regarded as a member of the husband's family for purposes of landholding; even the labour she contributed did not entitle her proprietary rights in the husband's land. As it were, a widow's well-being was provided for in the practice of liverate (also called wife inheritance), a custom under which a deceased's brother or next of kin took the widow as his wife and looked after her accordingly. In the alternative, a widow could choose not to remarry in the family but acquire occupational rights in the deceased's property by virtue of her children's interests therein. 3 Consequently, a female member of the family could only enjoy usufruct under the auspices of her father, husband or any other male head.

With the coming of colonialism, the socio-economic set-up in the traditional society started to crumble. The introduced cash-cropeconomy made it impossible to confine the people to family or clan land as such. Men in particular moved to towns and plantations to work for cash. New land tenures were introduced, production was no longer done on family basis and went beyond the mere purposes of subsistence. After independence, new policies further affected both the traditional land tenure and social organization. Under the policy of Ujama ${ }^{4}$ and Self-reliance, people were moved to Ujamaa villages which became the new social organization and focal points for economic development. All these changes, however, did not completely erode customs and usages that regulated property relations. Traditional rules continued to apply, although without the requisite social values as before. It is in fact the coexistence of the two that was to have a significant impact on women's rights, as the following discussion will show.

3 See R.W. James and G.M. Fimbo, Customary Land Law of Tanzania: A Source Book, East African Literature Bureau, 1973, pp. 188-189.

4 African socialism. 


\section{Position of the Law}

Rules on inheritance are now to be found in the Local Customary Law Order (Declaration No. 4) 19635 , a result of efforts made by the Government since 1960 to codify customs and usages of patrilineal tribes on personal matters. The Declaration upholds the universal patrilineal principle of inheritance that descent is traced through males. It does not apply to matrilineal peoples who trace kinship through females, whereby a man's principle heirs are his uterine brothers and his sisters' sons. It should be noted, even so, that in both cases it is males who control family property. The Declaration contains Rules for the succession of self-acquired property, family and clan lands. In Tanzania all land belongs to the public and therefore, legally speaking, individuals may only occupy and not own land, but in practice the difference between the right to use and the right to own land is negligible. Hence the continued use of the terms family and clan land in the Declaration. There are specific Rules for daughters and widows for the different types of property.

\subsection{Daughters' Rights}

Self-acquired property means property obtained through efforts of an individual or a family, and in the case of land it means that which is acquired through clearing virgin lands, usually with the permission of village govemments. By virtue of Rule 26 of the Declaration, the deceased person's sons and daughters have an exclusive right to inherit his property. Distribution of the property is to be done according to "degrees" whereby children are categorized depending on their mothers' positions in a polygamous marriage. The deceased's eldest son by his most senior wife will be in the first degree and thereby the main heir. If there is no son in the first house, then the main heir will be the eldest son from any of the other houses. All other sons regardless of their mothers' seniority will be in the second degree. Then come daughters who will be in the third degree, again irrespective of what position their mothers occupy. Under the rules the main heir is entitled to the biggest share. Thereafter property goes to the children in the second degree, each of whom shall get a bigger share than any of the children in the third degree. For children in the second and third degrees, distribution is according to age: the older the more the property, provided that as a whole males should get more than females. In this latter respect, age is not a factor. Thus, for instance, if there were twenty-four cattle distribution would be:

$$
\begin{array}{ll}
\text { First degree: } & \text { son, age } 23 \text { - } 9 \text { cows } \\
\text { Second degree: } & \text { son, age } 20 \text { - } 5 \text { cows } \\
& \text { son, age } 14-4 \text { cows } \\
\text { Third degree: } & \begin{array}{l}
\text { daughter, age } 25-3 \text { cows } \\
\text { daughter, age } 18-1 \text { cow }
\end{array}
\end{array}
$$


One may venture to say the system of self-acquired land might offer an opportunity for women to obtain pieces of land outside the purview of the Rules. Theoretically this should be possible, and it is quite probable that there are women who have obtained land in this way since it is normally distributed by respective village authorities. In practice, however, this may be hard to realise. Three main reasons have been advanced. First, it is an established norm in the villages that land is allocated to the head of a kaya, homestead, who is, in most cases, a man; secondly, given that men are still regarded as heads of family, there is a big possibility that the husband might step into the shoes of his wife even if that property is allocated to her; thirdly, if the wife dies intestate there is a likelihood of the property merging with that of the husband and thus becoming indistinguishable therefrom. If then the wife's self-acquired land falls into the husband's hands and he happens to die intestate, the Rules will definitely come into play. 6

\subsection{Family Land}

Family land today connotes more than what it was in the traditional society. Initially it meant land which was commonly owned by people of the same family lineage and which was subject to the traditional rules of land tenure. But, as mentioned before, new policies and especially the Ujamaa villagisation move watered down the concept of family land in the original sense. In these villages, farming is done collectively by all members of the village but individuals may still keep small plots, family holdings or homesteads as they are commonly known. These are what may now be regarded as family land to which the Rules also apply. Rule 31 provides that:

If there is only one child, it will inherit all the property but if the child is female she cannot inherit family land which she is allowed to use for her life without selling it. Nevertheless rule 20 has to be followed.

Rule 20 deals with clan land which we look at next.

\subsection{Clan Land}

Land tenure on the basis of clans must have been considerably affected by the villagisation programme under which people were moved from traditional holdings to new collective villages. Nonetheless, in some parts of the country like Kilimanjaro and Kagera regions,

6 Gondwe, Z.S., Female Intestate Succession to Land in Rural Tanzania: Whither Equality?, Tanzania Law Reform Bulletin, Vol. 2, No. 2, December 1988, p. 49. 
traditional land tenure was not completely extinguished. Clan land is subject to Rule 20 which provides that:

Women can inherit except for clan land which they may receive in usufruct but may not sell. However, if there is no male of the clan women may inherit land in full ownership.

However, the Rules do not make any clear distinction between family and clan land. As seen above, Rules 20 and 31 have to be read together although the two terms are used interchangeably. In summary, therefore, daughters have the possibility of inheriting selfacquired land subject to the "degree" categorization that gives preference to males as provided for in Rules 26 and 30 of the Declaration. Full ownership envisaged under Rule 20 may only be attained if there is no male member of the clan; but the nature of family network in Tanzania and Africa in general renders the rule ineffectual. Male relatives in a clan have never been scarce.

\subsection{Widows}

The declaration basically restates the traditional notion that wives are not members of the husband's family for landholding purposes. According to Rule 27 a widow has no share of the inheritance if the deceased left relatives of his own clan; her share is to be cared for by her children just as she cared for them. If a deceased husband leaves no relative whatsoever, his wife will be entitled to inherit all his property subject to Rule 20 which states that a woman cannot inherit family or clan land. 7 Then there are two more alternatives in Rules 62 and $66 \mathrm{~A}$. Rule 62 provides that a widow may be asked whether she wishes to live as a wife of one of the husband's relatives. If she declines the offer she is free to return to her family but no bride price will be refunded to her parents as required by customary law. Under Rule 66A a widow may choose a relative of the deseased husband to live with as his wife or she may opt to remain together with her children in the house of her late husband as an independent member of the family. For a widow who did not get children the position is given in Rule 77(1): "The moveable and immoveable property acquired during the married life shall be devided into two equal parts after the debts of the deceased husband have been paid. The widow shall receive a twentieth part of one half for every year of married life. Regarding immovable property she shall receive part of the land in the same proportion and shall enjoy the usufruct thereof until she remarries or dies." In the case of perennial crops she shall be entitled to receive part of them for her use until remarriage or death. 8 It should be noted that what a childless widow gets under Rule 77 is actually maintenance and not a

7 Rule 50 of the Customary Law Declaration; see also R.W.James and G.M.Fimbo, op.cit., p. 193.

8 Rule 77(2) of the Customary Law Declaration. 
share from the husband's estate. Thus the general principle of usufruct remains valid for crops, house or land, as the case may be. In the event of death or remarriage, all immovable property shall revert to the deceased husband's family. 9

\section{Equality and the Rules}

There is no doubt that the Rules discriminate against women and afford them only limited rights to inheritance. The first attempt to upset the Rules on the basis of equality was undertaken in the case of Verdiana Kyabuje v Gregory Kyabuje10. In that case, two daughters appealed to the High Court against lower courts' judgements on the distribution of land as per Rule 20. They argued, inter alia, that:

The magistrate in his judgment was influenced by a theory that women are of inferior complex to men, by depriving the appellants of their share of shambas (plots). Such decision is against universal justice and prejudicial to the dignity of women, who have a right of equality to men.

Although the judge expressed sympathy with the appellants, he felt that his hands were tied by the law. He said that any variations must be initiated by altering customs of the community where they originate. As such, "if a customary law draws a distinction in a matter of this nature between males and females, it does not fall to the court to decide that such law is inappropriate to modern development and conditions. That must be done elsewhere than in the courts of law". On the contrary, Justice Saidi in the case of Ndewawosia Ndeamtzo $v$ Immanuel Malasi 11 held that it was high time the cherished principle of equality was given force. In an elaborate judgment he said:

The idea of preserving clan land for clan members would appear to be a good principle, but it depends on the circumstances in which that principle is preserved. I would not be prepared to go to the extent of saying that such a principle is good in all circumstances and at all times. In Tanzania, as in all other places in Africa and elsewhere, the idea of equality between men and women has gained much strength. The time has now come when the rights of daughters in inheritance should be recognised.

9 Rule 77(4) ibid.

10 (1968) High Court Digest (H.C.D.) 499.

11 (1968) H.C.D. 127. 
Despite its progressive stand the judgment did not find favour with any of the subsequent cases of inheritance. Between 1968 and 198812 it stood in conspicuous isolation as the High Court and the Court of Appeal reaffirmed the Rules from one case to another. There were only occasional observations that the Rules were discriminatory, but it was seen as the role of the legislature to change the law. Government and Party policies as well as constitutional declarations appeared to have had little impact on the creative role of the courts. On the other hand, it is doubtful whether such considerations would have had any consequence given the Court of Appeal's ruling that the political and civil rights then contained in the Preamble were not legally enforceable as that was not part of the Constitution. 13 Thus the remedy seemed to lie only in legislative intervention. This occured in 1984 when, following The Fifth Constitutional Amendments, the Bill of Rights was enacted. It provided in Articles:

13(1) All people are equal before the law and have the right, without discrimination of any kind, to be protected and to be accorded equal justice before the law.

13(4) It is forbidden for any one to be discriminated against by anyone or any authority which is exercising its powers under any law or function of the authority of the state or the Party and its instruments.

It was along these lines that Justice Munyera held, in Peter Byabato v Pastory Rugaimukamu14 and Gabriel Vallery v Birungi Balilemwa15, that a woman's legal disability to dispose of clan land was contrary to Articles 13(1) and (4). The propriety of Rule 20 was also extensively discussed in the context of the Bill of Rights and international Human Rights Conventions by Justice Mwalusanya in the case of Bernardo Ephrahim v Holaria Pastory and another16. In this case, Holaria, the first respondent, inherited some clan land from her father by a valid will. Finding that she was getting old, senile and having no one to take care of her, she sold the piece of land to the second respondent. Shortly after sale, her nephew filed a suit in a Primary Court to have the sale annulled. The Primary Court did so on the basis of the relevant customary law that women had no power to sell clan land. The District Court, invoking the Bill of Rights, held that Holaria had the right to sell clan land and that the appellant was at liberty to redeem it upon reimbursing the purchase price. It

12 See Clementina Tibengwa v Traseus Kabwogi (1978) Law Reports of Tanzania No. 49; Agrein Rwehumbiza v Ephrahim Kahimba HC. App. No. 28/1983 (Mwanza unreported); Deocres Lutabana v Deus Kashaga HC. App. No. 1/1981 (Mwanza unrep.).

13 Attorney General v Lesinoi Ndenai and two others, Civil Appeal, Criminal Appeal No. 52/1979; Cr. App. No. 53/1979.

14 HC (PC) C. App. No. 252/1986 (Mwanza unrep.). This case might have been per incuriam if decided before March 88 when the Bill of Rights came into force.

15 HC (PC) C. App. No. 49/1988 (Mwanza unrep.).

16 HC (PC) C. App. No. 70/1989 (Mwanza unrep.). 
was against this decision that he appealed to the High Court. After reviewing policy statements and various Human Rights Conventions to which Tanzania is a signatory, the judge concluded that the principles enunciated therein povided a standard below which any civilised nation would be ashamed to fall. $17 \mathrm{He}$ further found as a fact that Rule 20 of the Declaration was discriminatory and therefore inconsistent with Article 13(4) of the Constitution. As such, he took Rule 20 to have been automatically modified by Article 5(1) of the Constitution which provided that the law before 1984 had to be construed with such modifications, adaptations, qualifications and exceptions so as to bring it into conformity with the Fifth Constituional Amendments. Hence, the position in the view of the Court now is that:

Females just like males can now and onwards inherit clan land or self-acquired land of their fathers and dispose of the same when and as they like. The disposal of the clan land to strangers without the consent of the clansmen is subject to the fiat that any other clan member can redeem that clan land on payment of the purchase price to the purchaser. That now applies to both males and females.

The Judgment in Holaria Pastory and indeed the provisions of the Bill of Rights will have far reaching implications not only for Rule 20, but also for other Rules in the Declaration and laws that discriminate on the basis of gender or otherwise. In particular, the Bill of Rights has provided women with a firmer ground on which laws that perpetuate inequality may be dismantled.

\section{Is it the End of the Road?}

The foregoing exposé shows that there is now at least a solid legal framework within which women's equal rights may be pursued. But Justice Mwalusanya wams that the legal framework is but part of the long road to women's liberation. The question is, therefore, whether legal guarantees alone suffice to effect the desired change, especially when it involves customs which are considered die-hards. A legal scholar expressed his doubt if the courts' newly found jurisdiction to declare the Rules unconstitutional may not fail to translate into operational reality due to the society's continues prejudices against women. He contended that sexual equality would only be attained when men and women are regarded equal. As this involves changes in attitude, he further argued, it may be more appropriate to persuade

17 The Doctrine of Ujamea and Self-Reliance which rejects discrimination of any type; the Universal Declaration of Human Rights (1948) incorporated in the Constitution of Tanzania as per Article (9)(1)(f); Convention on the Elimination of All Forms of Discrimination Against Women; African Charter on Human and Peoples Rights Art. 18(3); Intemational Covenant on Civil and Political Rights Art. 26. 
men rather than to impose a new regulatory mechanism, that is, norms of equality ${ }^{18}$. We think, however, that while this argument might be valid, the extent to which attitudes can play any role is a matter of fact to be considered within the confines of a particular subject. It should be remembered that in the traditional society the existence and the unity of the clan rested upon the collective heritage of land, such that nules of inheritance were concerned more with protecting clan land than the fact that men considered themselves superior. As if to make up for this inequality, the rules tried to be equitable in the circumstances of the day. Thus, for instance, the more advantageous right that a man had went together with definite obligations that were seldom neglected. A divorcee's or a widow's subsistence was always provided for by her male relatives. Therefore, if there is to be a discussion it has to be on the change of attitude towards rights and obligations arising from the rules before one comes to the conclusion that attitudes will always bog down legal reforms. That do the majority of the cases indicate? The case of Holaria shows how an old and helpless widow lived in misery with the "clanman" appearing only to claim land. In another case, that of Vicensio Tibo $v$ Sarapion Cyprian19, an old lady bequethed by will a plot of land to her grandson (her daughter's son). The grandson had actually grown up with the old lady and was the only one who took care of her during old age and illness until she died. After her death a clan member successfully challenged her capacity to dispose of the land. In Saidi Kasisi v Melensiana20, a very old widow who bore only daughters all of whom were, at the time, married was evicted from her late husband's house by a stepson, who was in fact brought up by her. The court refered the case to the clan elders where it was to be decided under customary law. In Bilimbasa Zacharia v James John 21 a father, before he died, distributed a plot of land to his son and two daughters. After his death one of the daughters, then a minor, was placed under the care of the brother according to customary law. He did not fulfil his duty, sold his own piece of land and even that earmarked for the upkeep of the minor. She sued through her next friend but the Primary Court dismissed the suit on the strength of Rule 20. It was only on appeal to the High Court that she succeeded. In the first two cases no clan member came to the rescue of the old ladies when they were old, sick and needy, but only emerged to "enforce" customary law. In the third case the appellant abdicated responsibility under customary law and yet used the same to assert his customary right as a man. Is it not clear then that the social values that underlined customary law have long been discarded? Invariably, this is a fact which has rarely been acknowledged when dealing with the Rules. As Jane Connors aptly says:

Traditional customary law was appropriate to the traditional society within which it developed, a society which was based on a subsistence economy and characterised by

19 HC. C. App. N. 158/1981.

20 HC (PC) C. App. No. 150/1986 (Mwanza unrep.).

21 HC (PC) C. App. No. 203/1982 (Mwanza unrep.). 
self-sufficient joint family organization. Within this was an elaborate system of reciprocal obligations between members of the family which sought to ensure that the needs of every member for food, shelter and clothing were satisfied.22

Are these the circumstances under which the Rules on inheritance have been applying? The foregoing cases cast a doubt. Muna Ndulo points out that development and industrialization have caused a breakdown of the traditional social order. The society is now highly individualistic, competitive and acquisitive. 23 The social fabric that characterised the Rule is no longer there. Is it not true, then, to use Justice Saidi's words in Ndeamtzo's case, that:

It is abundantly clear that this custom, which bars daughters from inheriting clan land and sometimes their own father's estate, has left a loophole for undeserving clansmen to flourish within the tribe. Lazy clan members anxiously await the death of their prosperous clansman who happens to have no male issue, and as soon as death occurs they immediately grab the estate and mercilessly mess up things in the deadman's household, putting the widow and daughters into terrible confusion, fear and misery.

Will persuasion really work in such circumstances? While we agree that social attitudes may be relevant in giving force to legislative measures, we should avoid the danger of tuming it into a catch-phrase. We have tried to show above that in today's circumstances men are driven more by the desire to grab than the fact that they do not take women to be their equal. Clansmen are no longer concerned with the plight of children and women displaced by death or divorce. Thus the enactment of the Bill of Rights is an important step towards realising equal rights for women especially in matters of inheritance. As noted by many scholars, legal reform has to go hand in hand with social and economic changes in other spheres of private and public life to ensure real equal opportunity for all citizens. But such changes will not come on a silver platter, deliberate steps have to be taken as a starting point. We should therefore hasten to add that:

While law is not the sole factor in the determination of women's status, the elimination of discriminatory laws and introduction of affirmative laws are essential first steps in the achievement of equality for women. 24

This is also acknowledged ty today's lawmakers.

22 Connors, J., The Legal Position of Women, in: Women in Sub-Saharan Africa, The Minority Rights Group, Report No. 77, p. 12.

23 Ndulo, M., Widows Under Zambian Customary Law and the Response of the Courts (unpublished), 1984, p. 22, quoted in Connors, ibid., p. 13.

24 Connors, J., op. cit. p. 15. 


\title{
ABSTRACTS
}

\section{Family Law Reform and the Integration of the Laws of Succession in Zambia}

\author{
By Chuma Himonga
}

In 1989, Zambia enacted two important statutes, the Intestate Succession Act and the Wills and Administration of Testate Estates Act. The Intestate Succession Act, especially, has been described as a big landmark in the Zambian legal history. It attempts to reform and integrate the customary laws of succession existing before its enactment. The reason for the above acclamation of this Act lies in the social and legal problems it seeks to solve for a large section of people in the country, especially widows and children of deceased men. The Wills and Administration of Testate Estates Act, on the other hand, provides for the law goveming testate succession. This paper examines these two Acts as an aspect of the implementation by the Zambian Government of its policy of reform of family law as a whole in Zambia. The paper concludes that while the Zambian Government remains committed to the reform of family law, the progress of implementation of this policy has been, and is likely to continue to be dogged by social, institutional and bureaucratic impediments as well as problems of requisite resources as reflected by the experience with the enactment of the two succession law statutes.

\section{Legal Developments on Women's Rights to Inherit Land under Customary Law in Tanzania}

\section{By Rose Mtengeti-Migiro}

The rights of women especially those pertaining to land inheritance has been one of the most controversial legal issues since Tanzania's independence almost three decades ago. During the period preceeding colonialism, that is during early traditional society which was predominantly patrilineal, land was collectively owned by the clan but was apportioned to family units under the authority of a male head of the family.

The socio-economic set-up of this society started to crumble with the advent of colonialism, and, after independence new policies also affected traditional land tenure and social organisation. Nevertheless, customs and usages that regulated property relations were not 
completely eroded, such that traditional rules were still applicable despite the absence of the social values required before.

The inclusion of the Bill of Rights in the country's Constitution in 1985 made it possible for women to pursue their rights to equality within the confines of a solid legal framework. It is within the context of this development that this paper seeks to examine the issue of women's rights to inherit land. The importance of this issue is particularly underscored by the fact that land remains one of the major means of livelihood for the majority of the Tanzanian population, half of which is comprised of women.

\section{The "Barbarians" and International Law}

\section{By Dieter Dörr}

In the course of the European expansion in the age of colonialism, the terms "barbarians" (John Stuart Mill) or "die Wilden" (Immanuel Kant) have been introduced to the rapidly developing field of modem international law in order to support the argument that the territory of the overseas dependencies of the European countries had been res nullius before colonization. The legal term "die Wilden", for example, dates back to the 18th and 19th century and stands for the "lawless freedom" of the North American Red Indians as seen by the European international lawyers.

The article explains the background of the different uses of the terms and their legal implications, starting with the papal bull of 1344, in contrast to the concept of the "civilized nations". The example of the Cherokee Federation in North America proves that the facts did not support the dogma. The Cherokee, as many other North American and African tribes, had a highly developed scheme of communal organization within their federation, which was seen, by Benjamin Franklin, as a model for the projected confederation of the English colonies.

The North American state practice took respect of these facts, as the contracts with the Indian nations and tribès were subject to the principles of international law. This state practice had great influence not only on the adjudication of the US Supreme Court, but also of the Supreme Court of Canada and of the International Court of Justice. The author comes to the conclusion that there is no factual or legal basis for the assertion that the territory of the colonies had to be considered as res nullius. 